\title{
Folktales and Short Stories to Blend Culture and Language Competence ${ }^{1}$
}

\section{(Leyendas y cuentos para combinar cultura y competencia lingüística)}

\author{
Cinthya Olivares Garita ${ }^{2}$ \\ Universidad Nacional, Costa Rica \\ Jorge Altamirano Alvarado 3 \\ Universidad Nacional, Costa Rica
}

\begin{abstract}
The aim of this research is to study the use of literature-based cultural material to reinforce speaking and writing skills by using folktales (general culture) and short stories (home culture) in oral and written expression in the English Teaching major. The analysis of a questionnaire for teachers and students indicates that those texts are rarely used to strengthen the productive skills. Based on this, a proposal has been devised to blend world and home culture with language competence to develop written and oral activities in the classroom.
\end{abstract}

1 Recibido: 16 de agosto de 2019; aceptado: 25 de febrero de 2020. An earlier version of this study "Folktales and Short Stories: Culture and Language Competence All in One," was presented at the Southern Cone TESOL Conference, July 17-20, 2019, in Curitiba, Brazil.

2 Campus Pérez Zeledón. Correo electrónico: cinthya.olivares.garita@una.ac.cr

3 Campus Pérez Zeledón. Correo electrónico: jorge.altamirano.alvarado@una.ac.cr

Letras 68 (2020), ISSN 1409-424X; eISSN 2215-4094 


\section{RESUMEN}

Esta investigación estudia el uso de información cultural basada en literatura para reforzar las destrezas orales y escritas, mediate leyendas (cultura general) y cuentos (cultura local), en los cursos de expresión oral y escrita de la carrera Enseñanza del Inglés. El análisis de un cuestionario diagnóstico para profesores y estudiantes muestra que los textos son poco utilizados para fortalecer las habilidades lingüísticas de producción. A partir de ello, se elabora una propuesta para unificar la cultura local y la general con la competencia lingüística para desarrollar actividades escritas y orales en las clases.

Keywords: teaching English as a foreign language, oral and written expression, use of literary texts, local culture

Palabras clave: enseñanza del inglés como idioma extranjero, expresión oral y escrita, uso de textos literarios, cultura local

Literature is considered a tool to describe the world and its peoples. In certain EFL or ESL contexts it is rarely used to enhance both cultural knowledge and linguistic skills. Folktales and short stories can be used in oral and written expression courses as they are considered texts that exploit cultural themes and may raise students' awareness of different worldviews along with behavior and social practices. Teachers may incorporate three types of cultural materials into an EFL classroom: target culture materials, learners' own culture materials and international target culture materials. The integration of these materials can enrich cultural knowledge and strengthen the four linguistic skills if they are properly chosen and adapted to the course syllabus.

World and native cultures can be portrayed by using folktales and short stories in language teaching. This paper revolves around offering EFL instructors practical ideas on how to use cultural information in folktales and short stories to help students reinforce the speaking and writing skills. To accomplish this, researchers will first refer to the importance of integrating world culture and native culture materials 
to teach those two linguistic skills by presenting the results of the data collection instruments administered to professors and students of the English Teaching major. Based on the data collected, a sample unit including a couple of folktales and short stories was designed for teachers to use in oral expression and composition courses.

\section{Literature Review}

\section{Literature in the Foreign Language Class}

Literature is an important manifestation of people's perceptions of the world and a re-creation of their reality. It also involves a reconstruction of symbols and meanings to represent the unknown. Traditionally, the role of literature in language classes has been oriented toward those who have intellectual capacities to enrich their knowledge of the world. In language teaching, literature was used to learn about foreign cultures, language structures, and fine arts in general. However, through the years, studies in second language acquisition have shown that a literary text can also be a useful tool for students. Thus, the four language skills can be developed through the use of pieces of literature at the same time that literary competence can be achieved. In addition to this, texts can be approached to enhance the ability to develop critical thinking.

Literature is considered one of the main ways to raise cultural awareness since the language used along with the social manifestations corresponds to cultural patterns that reflect the systems of different societies. When learning a second language, the target culture is a fundamental component that is linked to it. In simple terms, literature is not different from any other linguistic task students do in class. That is, students produce linguistic structures to achieve communication. Littlewood describes five perspectives on literature and language teaching that could be used as starting points when teaching language by using literary texts: 
- Literature provides instances of language structures in use, which can form the basis for instruction and practice in the language skills, especially reading comprehension, grammatical analysis and explanation. If language is taught as a whole, the text may be used as a tool to go over reading strategies to identify the main ideas, the details, and the author's point of view. Likewise, the structures used in the text may serve as the basis for grammatical instruction on new points, for review, or to reinforce the structures already learned.

- Literature may help students become capable of sensitivity to stylistic variation. Language varieties are explored regarding how standard and nonstandard forms are used for stylistic diversity. Genres such as narrative, poetry and drama are characterized considering the features that give a particular literary text a specific format and language style. It is of particular interest that writers may use their local dialects; this leads to a gap between the students' language and the variety used in the text.

- A more precise contribution of literature revolves around the subject matter. Here the episodes, situations and characters are highlighted for the purpose of engaging the reader with the gist of the text. Then, a more content-based approach is developed at this stage as the elements of the text are explored mainly for class discussion or written tasks as well. Not only language skills but also content are linked so that students become critical language learners. The connection between language and culture becomes more evident at this stage since the situations portrayed in the text are real-life situations faced by the characters in the literary text.

- Appreciation is now the next stage after strengthening language skills and learning literary approaches. What is expected here is to interpret the author's main point or underlying theme. Once again, class discussions and written work are expected as ways 
for the students to use the target language in a more parallel and integrated fashion.

- The final stage is reached when students can step outside and place the work in its historical context. Thus, facts are emphasized so that social roles along with linguistic and intellectual development of the foreign culture serve as referents for the points studied in the class. ${ }^{4}$

These five perspectives may also be used to select appropriate texts for different classes. Each class has very specific objectives that can be fulfilled depending on the suitability of the materials used. Literature contributes by offering a wide array of genres and themes for the students to choose the ones that suit their learning needs.

\section{The Role of Authentic Materials to Teach Language and Culture}

Another outstanding point to consider when teaching language and culture is authentic material. It can increase students' motivation to learn and expose them to real-life language used in naturally occurring situations. Hajrulla remarks that "today, with the help of technological developments, we have access to many sources easily and quickly. Almost all the printed materials are on the Internet in electronic forms and we can easily search anything anytime. As a result, we do not lack cultural content to use in our classrooms." 5 Some authentic materials such as brochures, newspapers, songs, and films raise students' interest to discover and explore cultural manifestations in real contexts. McKay suggests three types of cultural materials: target culture materials, learners' own culture materials and international target culture materials. ${ }^{6}$ She remarks that international

4 William T. Littlewood, "Literature in the School Foreign Language Course," Modern Languages 56, 3 (1975): 127-131.

5 Veneranda Hajrulla, "Bringing Cultural Content and Authentic Materials to Enhance ProblemBased Learning in EFL Classes," Lingua Mobilis 5, 38 (2012): 2-14.

6 Hajrulla, 2-14 
target language materials are the best as long as they cover cultural knowledge from around the world using the target language. These three types of materials are quite useful since students get involved with their own culture, the target culture and other foreign cultures, thus leading to their having a broader perspective of their own culture and other cultures. There is, therefore, no reason not to include these texts with full cultural content. In a language classroom, students are frequently asked what topics they would like to discuss if the syllabus allows it. When dealing with the target culture, though, the language used must not prevent comprehension. Students usually feel that they are not able to go beyond a simple analysis of the content of a text because their proficiency level is low; however, if the text is carefully selected, that may be solved.

Furthermore, literary texts develop plots that may seem totally unreal for the students' context. In this light, the teacher might get the students to be sensitive to cultural and linguistic conflicts that arise when dealing with the target culture. The instructor can present situations that may take place when interacting with foreigners or when visiting the target culture. A concept that may be addressed in this language-culture relation is negotiation of meaning. Students need to know that as they move on, there comes a time when more advanced communicative skills must be handled to fulfill the speakers' needs. This means that cultural codes must be interpreted for fluent communication. Cultural information often provided by teachers helps learners understand misinterpretations or biases that students assume are true. Learning a language is not necessarily the mastery of vocabulary, grammar and pronunciation but rather a mixture of culture-bound linguistic and non-verbal clues. The use of authentic materials in the English class requires three fundamental steps: 


\section{Criteria of Authentic Materials}

The purpose of the English class is to teach language for communication, but not all material is suitable for that purpose. The teacher should take the time to choose the material carefully. Berardo suggests these criteria for selecting authentic texts:

a. suitability of content: students' interests, needs and abilities

b. exploitability: students' competence and teaching purposes

c. readability: language of the text

d. Based on the previous points, the teacher can select the material that fulfills the students' needs. ${ }^{7}$

\section{Integrated home and target culture}

Authentic material provides cultural content from the target language. It shows the learners how the language is used by native speakers and what the components of culture are. Because of the influence of the foreign culture, there should be cross-cultural comparisons that include the students' own culture along with the target culture. That implies that both cultures should be part of the contents developed.

\section{Effective activities}

Effective classroom activities are required to engage the students in the class. If the teacher uses authentic materials, the activities must make use of such materials. As a result, the students are motivated to participate when teachers design interesting activities to learn the language.

In the case of short stories, they seem very suitable to use. Since they are short, and not overloaded with many details and characters,

7 Loli Safitri, "The Use of Authentic Materials in the EFL/ESL Classroom," Journal of English Education 3, 1 (2017): 23-26. 
it is easy for the students to understand them. There are four advantages of using short stories. First, short stories are practical as they can be covered in a single class. Second, they are not complicated for students to work on individually. Third, short stories have a wide range of themes for different types of students. Finally, short stories can be used with beginners as well as with advanced students of all ages. The use of short stories should encourage the students to use their prior knowledge so that the learning is student-centered. Nevertheless, teachers play a significant role as they must choose the text to be used in class, and help the students understand the story by assigning diverse activities that strengthen the four linguistic skills. Teachers must make the selection carefully. When reading the story, students should be able to realize that they can read, understand and finish it so that it will give them a feeling of achievement and self-confidence. Apart from the length of the text, instructors should consider other criteria to choose the text: the students' needs and language proficiency, the linguistic level of the text, and the amount of prior knowledge required to understand the material. The importance of these criteria is that the vocabulary and sentence structure of the text must be in accordance with the students' level. Some short stories with very archaic words and excessive slang should be avoided as students may find them difficult to follow.

Short stories allow instructors to focus on the four language skills in different student populations. These texts can provide meaningful content which can enhances the teaching of language and culture. Additionally, short stories can be very beneficial for the development of linguistic skills since they can be used in a wide array of activities such as discussion, writing and acting out dialogues, changing the characters, making up another ending, listening to the story online, finding key words and replacing them with synonyms. ${ }^{8}$

8 Parlindungan Pardede, "Using Short Stories to Teach Language Skills," Journal of English Teaching 1,1 (2011): 14-27. DOI: https://doi.org/10.33541/jet.v1i1.49. 


\section{Language and Culture}

In a globalized world, it is vital to interact with people who speak other languages. That is what language education concerns: making languages a means of communication to have access to others. Culture and language are strictly related. Language is part of culture; it is a transmitter of culture and the main tool for the internationalization of culture. However, the term 'culture' is thought to be very broad. Culture can be defined from a variety of perspectives depending on its oral or written aspects, whether we look at popular culture, and whether we consider special events, or daily practices. Kramsch states that there are two different ways of understanding culture. ${ }^{9}$ The first revolves around the study of the humanities. According to this view, culture is the way a social group mirrors itself and others through material productions such as art, literature, mechanisms of preservation and reproduction through history. The second way of understanding culture conceives the phenomenon as derived from the contributions of social sciences, including attitudes, beliefs, ways of thinking, behaving and remembering shared by members of a community.

Language programs that teach culture have often been criticized for engagement with cultural differences. In consequence, using culture as context for learning has been proposed to offer broader curricular approaches to language and culture. Another aspect of criticism concerns the superficial conceptualization of culture in language teaching programs and materials. Teaching materials tend to be simple and plain; they present facts rather than interpretations of cultural phenomena. They avoid explaining nuances and developing intercultural skills. Every day routines might prove misleading as they are symptoms of some underlying norms, attitudes or beliefs. In the case of language learners who are not provided with explanations

9 Janusz Arabski and Adam Wojtaszek, eds., Aspects of Culture in Second Language Acquisition and Foreign Language Learning (London: Springer-Verlag Berlin Heidelberg, 2011). DOI: https://doi. org/10.1007/978-3-642-20201-8 
of the underlying meanings, they are likely to face communication problems. Another common mistake is that culture cannot be framed only to refer to social practices such as cuisine, festivals and traditional dress. Such emphasis on differences leads to stereotyping the target group and emphasizing exotic differences between societies. ${ }^{10}$

The target language cannot be separated from its culture. Culture is defined as the customs, values, laws, technology, artifacts and art of a particular people. Culture in English language teaching materials should emphasize how native speakers of English use the language in their daily lives. Understanding the culture of the native speaker is a good way to use linguistically and pragmatically appropriate language. Learning about the target culture as well as about one's own culture requires language learners to know how to negotiate meaning and understand the communicative processes and cultural texts containing specific linguistic codes. In other words, it is very useful for learners to become familiar with the culture of English in order to comprehend the language. Cultural content exposes students to the language that they lack as non-native speakers. For instance, culture is an instrument that allows learners to comprehend the importance of speaking the target language.

\section{Teaching Culture}

For teachers to help students understand the target culture, they should start with their own frame of reference and then move on to the next stage. To teach culture, the following considerations should be taken into account:

1. Carefully plan and integrate cultural lessons and activities in the class.

2. Present cultural topics related to thematic units. Use cultural

10 Arabski and Wojtaszek. 
contexts for activities even if they focus on grammar.

3. Use varied techniques that develop the four language skills.

4. Use textbooks with illustrations and photos. Ask questions to elicit and analyze their cultural content.

5. Use cultural information to teach vocabulary. Discuss the connotations of words.

6. Use discussions, brainstorming and group techniques to develop cultural content.

7. Avoid using only facts, by including experiential and process learning.

8. Always use the target language.

9. Test cultural content just as language is tested. ${ }^{11}$

These recommendations on teaching culture are worth incorporating into the class as long as they help teachers to deal with the teaching of language and culture by developing the four language skills. Once again, we can notice how meaningful it is to relate any cultural theme to the language point being taught. By doing this, not only is language proficiency strengthened but also cultural content enhanced. This approach may provide more positive results in the classroom if it is developed on a regular basis. Another variable that must be considered is the teacher's expertise to teach culture. Over the years, language teachers have provided useful suggestions and activities to be incorporated and adapted in the classroom. Some of the most successful are role-play, hands-on projects, surveys, chats, inviting native speakers to the classroom, culture capsules, culture clusters, cross-cultural comparisons and posters.

Many of these activities require proper preparation together with authentic materials to make the teaching-learning experience engaging. Authentic materials enable students to interact with real language and cultural practices besides language. Learners feel that

11 Alice Omaggio Hadley, Teaching Language in Context (Boston: Heinle \& Heinle, 2000). 
they are learning a target language as it is used in the real world. Therefore, in any teaching context authentic materials should be used to fill the gap between language knowledge and social behavior, a natural barrier for speakers of foreign languages. Technology nowadays has an impact on how culture is taught in the language class. Through technology teachers have access to information from the context and from interaction with native speakers. Thus, that information becomes more reliable because the teacher is just the facilitator and not the primary source of knowledge. This contributes to creating a more critical view from the students as they are the ones who use the information provided and analyze it to give their own opinions or develop activities in which the language skills are reinforced by means of the content provided. Thus, it can be said that technology enables students to have a clearer picture of the target culture and become more critical.

\section{Challenges When Teaching Culture}

Another tenet when teaching language and culture deals with how to build cultural competence as teachers are faced with issues that may interfere with the development of the class because students may be and have misconceptions about the target culture. For this purpose, it may be useful to assess how appropriate a given activity is for the concept studied. Not all activities may fulfill the objectives established. If they do, the teacher must carefully decide whether the students will respond positively to the activity or feel reluctant to participate. Variables such as size of the group, age, gender and personality could affect the outcome. This is when lesson planning plays a central role to reflect on the dynamics of the class. Then the challenge of the content should be balanced. Students need to be challenged all the time, for they like novelty and variety in activities. When dealing with cultural content, challenge is always expected since there are lots of questions to answer and situations that are 
possibly new to explore.

Students' curiosity should awake their senses to open up to the new world in front of them, in this case, the target culture. Following, the activity carried out must trigger movement along the class cycle by building on the learner's experience. This step involves relying on students' concrete background knowledge as a tool to be used when comparing or analyzing cultural themes. This is usually utilized to make cross-cultural comparisons that are later discussed in pairs or small groups. The role of the teacher here is to guide the students to clarify if their assumptions about the new culture are true or not and help them build up knowledge. After this is accomplished, it is time to offer reflection and connection. Students connect everything they have learned to their existing knowledge so that their cultural baggage is broadened. This serves as a reflective time for them to internalize new knowledge and test it regarding its usefulness. This part of the lesson is crucial since students can comprehend what has been learned and probably get rid of what they consider to be stereotypes derived from their lack of cultural competence. The other stage of the classroom is devoted to examining a concept or framework. More abstract concepts are reviewed for the purpose of placing the cultural aspect in its sociocultural context. Social practices behind the theme may be the basis of its actual occurrence, which determine the extent to which it is regarded as a conventional situation or not.

On the other hand, the pragmatic component needs to be stressed as a means to actively engage in situations which are appropriate in a given context. Active participation is demanded from the students to show understanding and competence. By being actively engaged in the learning process, students demonstrate how suitably they might act in situations requiring their linguistic and cultural knowledge. The content learned should correspond pragmatically to how native speakers do in real life situations, so that it will lead to the development of both linguistic and pragmatic competence. 
Teachers must consider the pace at which students learn in order to determine the sequence of their learning process. Too much content may overwhelm students who are beginning to learn about a new culture. Therefore, the information must be presented in a way that there is understanding and room for proper interpretation. This is usually done by means of activities that require time for the students to prepare, develop, discuss and reflect. In other words, it is a stepby-step procedure. Not all learners process information at the same time and rate, so approaching as many learning styles as possible can be a very successful strategy to be sure everyone is involved in the process. Some dominant styles such as the extroverted personality may take over in activities where discussion is essential leaving introverted learners behind. Teachers must be able to identify major learning styles to keep a balance in the classroom and permit the participation of all the students to assure effective learning.

Although it may seem complex, teaching language and culture does not have to be a hard task for teachers. It is expected that diverse situations may arise to cause certain discrepancies among learners because students have different backgrounds and beliefs. There could be instances in which some may think that their feelings are challenged by the target culture as what may be permissible in one culture may not be in another. Some students might take risks to even test their own tolerance while others may feel reluctant and express denial or discomfort. This is natural and does not have to be a burden for teachers who go the extra mile when adapting materials and designing activities that enhance the cultural component of language. Finally, it is also pertinent to foresee whether the various groups present in the classroom (cultural backgrounds) will enjoy the activities suggested by the teacher or if they will resist them. To deal with this, teachers must know their students well and be sensitive enough to avoid themes that may cause embarrassment or negative feelings. If a problem comes up, it is necessary to discuss it and explain why the topic was brought into the classroom. Since 
emotions may be affected when dealing with cultural themes, instructors must know what to do in those circumstances. ${ }^{12}$

\section{Methodology}

\section{Design}

This research was framed following a case study design; it includes the analysis of qualitative and quantitative data to determine the usefulness of literary-based cultural material in an oral expression course and a composition course in order to maximize language competence. The research questions that will lead this study are:

- How useful is it to integrate literary-based cultural materials in an oral expression and in a composition course to improve language competence and boost cultural awareness?

- What literary-based cultural materials can be incorporated into an oral expression and in a composition course to improve language competence and boost cultural awareness?

- How can literary-based cultural materials be used in an oral expression and in a composition course to improve language competence and boost cultural awareness?

After the data analysis, the researchers will propose a design to integrate short stories and folktales in those courses, based on the participants' responses. The scope of this research is descriptive. Fox and Bayat define descriptive research as that "aimed at casting light on current issues or problems through a process of data collection that enables them to describe the situation more completely than was possible without employing this method. ${ }^{13}$

12 Kate Berardo and Darla Deardorff, Building cultural competence: Innovative activities and models (Sterling, VA: Stylus Publishing, 2012).

13 William Fox and Mohamed Saheed Bayat, A Guide to Managing Research (Cape Town: Juta \& Co., 2007) 8. 


\section{Participant Selection}

This study took place on a state university campus located in the south of Costa Rica. The selection of participants followed a nonprobability sampling design. The group of student participants was deliberately selected. The sample population of students is representative and included 18 students from the oral expression eourse and 25 students from the composition course of the English Teaching major at Brunca campus UNA). Eight teachers of the faculty were also surveyed. Six teachers have 5 years of teaching experience and the rest of them have more than 10. All of them are teaching or have taught these courses.

\section{Data Collection Instruments}

For the collection of the data, two instruments were designed and administered. The first instrument aimed to gather information from the students' perspectives on the use of literary-based cultural material in these two courses. It included 6 different sections. The first was intended to collect personal information from the students such as gender, age, major, place of residence, level and course. For the second section, a summative five-point Likert scale was constructed to determine the use of literary-based cultural material in these courses. The values for this scale were: Very much, Much, Average, Little and No use. The third section involved a similar five-point Likert scale to establish the benefits perceived by the students from the use of literarybased cultural materials. The benefits included in this scale were taken from the contributions stated in Kilickaya's research. ${ }^{14}$

The fourth section aimed to define how frequently certain literature-based cultural activities are used in the courses selected for this study. For this data collection, a five-point Likert scale was designed

14 Ferit Kilickaya, "Authentic Material and Cultural Content In EFL Classrooms," The Internet TSL Journal 10, 7 (2004): 1-5. 
with the indicators: Very much, Much, Average, Little and No use. Section five helped researchers to explore how much each of the literature-based cultural activities listed above is used to improve language competence. Similarly, a point-five Likert scale was used with the same indicators. Finally, the sixth section was composed of two close-ended and three open-ended items. Basically, the section was aimed to elicit responses about the national and international literary texts they have read. Furthermore, the researchers posted two questions related to a Costa Rican literary text recently translated into English. The researchers wanted to take advantage of this contribution to enrich the activities developed in the EFL classrooms. The groups of students were asked whether they had read the book, whether they would like to use it in the respective oral or written expression course, and if so, how they would like to use the short stories in the development of their speaking and writing courses.

The second instrument was designed to garner information from the professors who are teaching or have taught the courses Oral Expression and Composition or any other related course. The goal of this instrument was to determine the use of literary-based cultural materials in the appointed courses of the English Teaching major. The instrument was composed of six different sections. The teacher questionnaire and student questionnaire are slightly different. The first section aimed to collect information about teachers' personal data such as gender, years of experience, course and major. The second section was designed to determine how much the different categories and types of literary-based cultural material in the Oral Expression and Composition courses were used. In a five-point level Likert scale, the values established were: Very much, Much, Average, Little and No use. The third section's objective was to identify the benefits received from using literary-based cultural materials in the EFL classroom based on the theoretical contributions of Kilickaya. ${ }^{15}$

15 Kilickaya, 1-5. 
It involved the use of a five-point Likert scale with values similar to those of the second section. The fourth and fifth sections focused on the frequency of use of different literary-based teaching activities in the courses mentioned and the extent to which those activities helped to improve language competence respectively. Both sections involved the use of a five-point level summative Likert scale with values similar to those ones used in the previous sections. The sixth section included three open-ended questions and two close-ended questions. The open-ended questions aimed to elicit the national or international short stories or folktales teachers would like to read and use in their courses and the activities they might develop to use those literary texts to improve language competence.

\section{Analysis of Data and Interpretation of Results}

The relevant data was collected through the administration of a student and a teacher questionnaire described above. The quantitative data of sections II, III, IV and V of both questionnaires were analyzed by calculating the mean scores of each criterion on the Likert scale, and is displayed in the tables below. The qualitative data of section VI of both questionnaires was evaluated by grouping some categories and displaying them also in tables. The findings drawn from these analyses has allowed the researchers to answer the main questions of this study.

\section{Results}

The analysis of the first inquiry of this study reveals the categories of literary-based cultural material that students from the oral and written expression courses and the teachers use or have used to learn and teach the language respectively. For the purposes of this study, the term literary-based cultural materials refers to "contemporary and traditional literary texts that use language in aesthetic, imagina- 
tive and engaging ways - to entertain, to move, to express and reinforce cultural identity and to reflect." ${ }^{16}$ According to the responses gathered in section 2, students taking the oral expression courses are more familiar with literary-based cultural material in the activities they develop (see table 1); in contrast, students from the writing courses have been less exposed to the use of these materials. In the case of the oral expression course, the type of literary-based cultural material least used was that of the students' own culture. Concerning the composition course, the type of material least used was international culture materials. All of these types of material obtained a relatively low mean from the students' responses. On this same note, instructors appear to be somewhat aware of the use of this type of material in their courses. The least used material that teachers have employed is that of their own culture and the most used corresponds to international culture.

16 Queensland Studies Authority, "English: Literary and Non-Literary Text Types Scope and Sequence," (Queensland, Australia: Queensland Gvoernment, 2007), June 13th, 2019, available at: $<$ https://studylib.net/doc/8738729/english--literary-and-non-literary-text-types-scope-and-s...> or $<$ https://www.qcaa.qld.edu.au/downloads/p_10/qcar_ss_english_literary.pdf $>$. 
Table 1. Categories of literary-based cultural materials

\begin{tabular}{|c|c|c|c|}
\hline & & Mean & \\
\hline $\begin{array}{c}\text { Categories of Cultural } \\
\text { Materials Used }\end{array}$ & $\begin{array}{l}\text { Oral Expression } \\
\text { Course }\end{array}$ & $\begin{array}{l}\text { Composition } \\
\text { Course }\end{array}$ & Teachers \\
\hline Target culture materials & 4.30 & 1.64 & 3.60 \\
\hline $\begin{array}{l}\text { International culture } \\
\text { materials }\end{array}$ & 4 & 1.52 & 3.75 \\
\hline Own culture materials & 3.30 & 1.56 & 2.60 \\
\hline
\end{tabular}

Source: Student and teacher questionnaires, section 2.

Part of the second section of the questionnaires was also an attempt to determine the types of literary texts used in the oral expression and composition courses by students and teachers of the major. The students from the writing course revealed that literary texts are not common among the material used (table 2); namely, in all the different types of literary-based cultural materials, the means were low. Furthermore, the least common type of literary text referred to fables and the most common was short stories. Regarding the oral expression course, the least common literary text was poetry and the most common was the short story. For both courses, short stories were the most used, according to the students. For the teachers, all the literary texts scored relatively low. The highest mean reported was short stories and the lowest was poems. 
Table 2. Types of literary-based cultural materials

\begin{tabular}{lccl}
\hline $\begin{array}{c}\text { Types of } \\
\text { Literary Texts } \\
\text { Used }\end{array}$ & $\begin{array}{c}\text { Oral } \\
\text { Expression } \\
\text { Course }\end{array}$ & $\begin{array}{c}\text { Composition } \\
\text { Course }\end{array}$ & Teachers \\
\hline Folktales & 3.10 & 1.32 & 1.60 \\
\hline Short Stories & 3.80 & 3.20 & 2.60 \\
\hline Fairy tales & 2.60 & 1.36 & 2.10 \\
\hline Poems & 1.36 & 1.24 & 1.50 \\
\hline Fables & 1.44 & 1.20 & 1.60 \\
\hline
\end{tabular}

Source: Student and teacher questionnaire, section 2.

Equally important, the analysis of section 3 of the student and teacher questionnaires allowed the researchers to determine the benefits of using literary-based cultural materials in the EFL classroom. The benefits that researchers listed according to the literature read included raising motivation, generating cultural awareness, providing authentic cultural information, providing exposure to real language, relating more closely to one's needs, supporting a more creative approach to teaching, expanding perspectives, assisting in negotiating meaning, expanding the understanding of communicative and cultural texts, and reinforcing language competence. The students' responses on the oral expression course revealed that this population highly believes that the incorporation of these materials boost a more creative approach to teaching. All the benefits listed obtained high scores; however, these students indicated that the incorporation of literary-based cultural texts does not relate too closely to their needs. For the students in the composition course, these materials provide exposure to real language, above all. It is worth noting that all the benefits listed obtained a high score; nevertheless, the interpretation 
of these students' responses allowed researchers to detect that these students believe that literary-based cultural materials raise their motivation somewhat. The teachers' responses revealed that, like the students, they believe that this type of material provides exposure to real language and authentic cultural information. Even though all the benefits used in the item scored high, the lowest score was given to the one that states that literary-based cultural material relates more closely to the students' needs.

Regarding the fourth section of both questionnaires, the researchers analyzed the percentages obtained from the Likert scale regarding the ways students and teachers have used literary-based cultural materials in the classroom. The possible ways include making comparisons of cultures found in the texts, inviting guest speakers to the classroom to tell a folktale, speaking about topics and identifying similarities and differences of the cultures in the text, problemsolving cultural issues found in the text, bringing sources of literarybased cultural information (newspaper articles, videos of animated folktales, short stories, etc.), dramatizing/role-playing situations of a scene or passage in the literary text, talking/discussing themes in the literary texts, playing games, carrying out reading activities, listening activities, saying proverbs and phrases taken from short stories, fables, fairy tales, folk tales, etc. In the students' responses on the oral expression course, inviting guest speakers to tell a folktale or short story received the lowest score whereas using videos of animated folktales or short stories and listening activities received the highest score. The responses of the students in the composition course showed that making comparisons of cultures in the texts was the least used, whereas the most used way of using literary-based cultural material was in reading activities. According to teachers, the least used way was inviting guest speakers to tell a folktale or short story and the most used was also in reading activities.

As part of this same item in section 4, students and teachers were asked to report on any different way to use literary-based cultural 
material in the courses mentioned other than the ones given by the researchers. Their responses were recorded to show some differences and similarities in their ideas (table 3). Students from both courses coincided with the idea of having oral presentations as part of the activities carried out along with the short stories or folktales in the classroom, as well as using authentic materials such as videos, articles or technological devices. The instructors mentioned two options to help students develop their creativity and broaden their knowledge of the language by using this type of material: modifying the end of stories and familiarizing students with written discourse.

Table 3. Additional Ways to Use Literary-Based Cultural Material

\begin{tabular}{|c|c|c|}
\hline $\begin{array}{l}\text { Oral Expression } \\
\text { Students }\end{array}$ & $\begin{array}{l}\text { Composition } \\
\text { Students }\end{array}$ & Teachers \\
\hline $\begin{array}{l}\text { - } \quad \text { Translating texts } \\
\text { - } \text { cultural materials } \\
\text { - Using pictures } \\
\text { that show different } \\
\text { cultures } \\
\text { - } \text { Discussing cultural } \\
\text { topics } \\
\text { - Short videos and } \\
\text { articles } \\
\text { - Group discussion } \\
\text { - Sharing opinions } \\
\text { about other cultures } \\
\text { with classmates } \\
\text { Watching short } \\
\text { videos } \\
\text { Technological } \\
\text { devices } \\
\text { Doing research }\end{array}$ & $\begin{array}{l}\text { - } \text { Writing paragraphs } \\
\text { - } \text { diffests from } \\
\text { that we can see it } \\
\text { better and talk about } \\
\text { the differences } \\
\text { - Writing essays } \\
\text { - Writing response } \\
\text { papers and critical } \\
\text { analysis } \\
\text { Making oral } \\
\text { presentations }\end{array}$ & 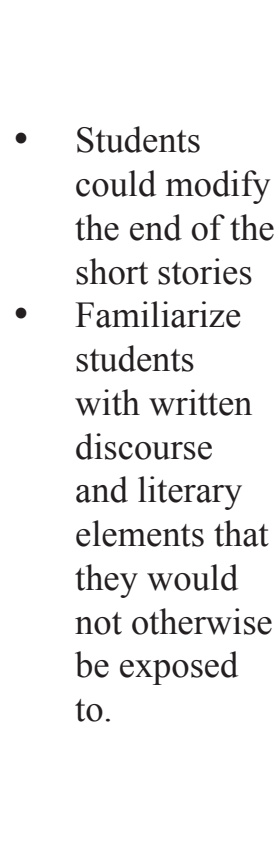 \\
\hline
\end{tabular}

Source: Student and teacher questionnaire, section 4 . 
Along the same lines, section 5 of the student and teacher questionnaires allowed the researchers take note of ways to use literarybased cultural materials to improve language competence: making comparisons of cultures found in the texts, inviting guest speakers to the classroom to tell a folktale, speaking about topics and finding similarities and differences of the cultures included in the text, problem-solving cultural issues found in the text, bringing sources of literary-based cultural information (newspaper articles, using videos of animated folktales, short stories, etc.), dramatizing/role-playing situations of a scene or passage of the literary text, talking/discussing themes in the literary texts, playing games, carrying out reading activities, listening activities, and sharing proverbs and phrases taken from short stories, fables, fairy tales, folk tales, etc. Students in the oral expression course selected bringing sources of literarybased cultural information like newspapers as the least used activity for improving language competence. They agreed that using videos of animated folktales or short stories can be an effective activity to improve their language level. For the composition students the lowest score corresponded to problem-solving cultural issues found in the text, whereas games is the activity with the highest mean.

In this same vein, students and teachers were asked to add more ways to use literary-based cultural materials to improve language competence. Students of both courses agreed that using authentic materials such as videos, movies, songs and books to improve language along with the folktales and short stories. In addition, the students of the oral expression courses coincided on activities like reading a short article or fairy tale, then interviewing a native speaker and finally making conclusions about what they might discover; comparing between how some problems are presented in real life and how they are represented on literature; doing impromptu-speeches; making oral presentations, holding discussions, and participating in talk shows and role plays; researching about different topics related to culture; reading several books during the semester; watching short 
videos; and finally, making portfolios. On the other hand, teachers stated that analyzing the role of the characters in the story and then simulating it is an effective way to use literary texts and improve language because developing output-based activities boosts the students' competence.

As part of section 6 (items 1 and 2), both students and the teachers were asked to provide the names of national and international literary texts that they would like to read to learn and teach language and culture respectively. For the international literary texts, students from both courses chose Asian literary texts. The teachers did not agree on any literary text in particular but assured that they would choose one specific cultural group and analyze its short stories or tales. For the national literary texts, students of both courses agreed on having Costa Rican legends (El Cadejos, La Llorona, La Tulevieja, La carreta sin bueyes) in the activities developed in the classroom. Teachers agreed on including legends and stories depicting the life and struggles of Costa Ricans in the countryside.

Additionally, students and teachers were asked in this same section whether they had read Short Stories of Anguish and Landscapes ${ }^{17}$. Most students from both courses- $72.2 \%$ from the Oral Expression course and 88\% from the Composition course-reported that they have not read those short stories. In the case of teachers, only $14.3 \%$ said that they have not read Short Stories of Anguish and Landscapes. However, $100 \%$ of teachers assured that they want to read them and use them in class, and a very small percentage $-15.6 \%$ in the case of the oral expression course and $14 \%$ of the composition course - are not interested in reading them.

Students and teachers were also asked to propose different ways of using Short Stories of Anguish and Landscapes to learn and teach language and culture at the same time (table 4). All three groups of

17 Carlos Salazar Herrera and María Luz Méndez Salazar (trans.), Costa Rican Short Stories of Anguish and Landscapes (Heredia, C. R.: EUNA, 2016); translation of: Carlos Salazar Herrera, Cuentos de angustias y paisajes (San José: El Cuervo, 1947). 
participants represented in this study came up with different ideas that cover all the linguistic areas, learning styles, ways of grouping and multiple intelligences. For the linguistic areas, there is a representation of each. For speaking, students and teachers put forward role plays, oral reports, talking about cultural similarities and differences found in a story and games. For listening, they suggested comprehension exercises and short videos. For writing, participants recommended short research projects; for reading, analyzing the texts to improve grammar. 
Table 4. Proposal of Different Ways to Use Short Stories of Anguish and Landscapes

Teachers

- Role plays

- Short researchbased projects

- Analysis and comparison of cultural aspects

- Depicting regional dialects and the life of the campesino/ country people.

- $\quad$ Raising awareness about the importance of preserving our customs and traditions and promoting appreciation of our native culture through role-plays, oral reports, games
Oral expression

Composition
- Discussing the short stories in small groups

- Short videos

- Understanding them and giving examples how they are presented in life

- Present what we learned in front of the class

- In listening comprehension

- Doing some research about the stories to understand the context

- Reading improves

- By representing those short stories with role plays

- Maybe listening to those short stories

- Role plays grammar

- Talking about similarities and differences between CR and USA literary texts

- Analyzing the lifestyle, vocabulary and other aspects that all the stories contain

Source: Student and teacher questionnaire, section 6 . 


\section{Conclusions}

The analyses of the data collected led researchers to the following conclusions:

1. Writing courses integrate fewer literary texts such as short stories and folktales into the development of the course activities. Teachers of these courses showed that it literary-based cultural materials can be included in their plans in many ways. Although it seems easier to integrate these materials into an oral expression course, writing course teachers are aware of the need to incorporate them and make a change in their lessons.

2. Target culture materials are the most used types of literarybased materials employed in both courses. Consequently, students of these courses are less exposed to national and international material involving the use of short stories and folktales.

3. Short stories are the most common literary-based cultural materials used in these courses. Poems and fables are not frequently used, but that can be taken advantage of to maximize language learning.

4. The inclusion of literary-based cultural materials in the oral expression and composition courses has many benefits. Students highlighted the importance of these materials to generate a more creative approach to teaching and exposure to real language. However, they believe that these materials do not relate to their immediate needs, as teachers also pointed out. In this regard, it is essential to cultivate students' and teachers' mindset. Cultural material is as important as any other type of material to strengthen not only bilingual learners' capacities to master the language but also bicultural learners' mindsets to broaden their worldview. 
5. The most common options found in the courses include using videos of animated folktales or short stories, listening activities and reading activities. Nevertheless, students do not often invite guest speakers to narrate a short story or use the literary texts to make comparisons of cultures in the text. Teachers' responses coincided regarding the most and least used ways of incorporating literary-based cultural materials. Oral presentations and changing the end of a story were the most outstanding activities suggested by both groups.

6. The activities that students and teachers selected that facilitate the improvement of learners' language competence were related to the use of authentic materials such as videos, newspapers and games.

7. Learners revealed that their interest in the integration of Asian and European folktales and short stories is high. Furthermore, national legends and stories portraying the life in the countryside were also selected as national cultural materials that students and teachers would like to incorporate.

8. The book of folktales chosen is composed of short tales depicting the way of living, struggles and feelings of Costa Rican people living in rural areas. Since it has not been read by many people, both the students and teachers are interested in using these short stories for language learning purposes.

9. Based on the students' and teachers' responses about how to incorporate short stories, the researchers designed a proposal to maximize language learning and teaching and broaden cultural awareness as well (table 5). A booklet of activities was prepared to facilitate the teaching of the language and cultural awareness in the oral expression and composition courses based on literary-based cultural materials. Of the three oral expression courses of the UNA English Teaching major, the one that might fit this proposal best is that related to topics on society and humanism. This is the first oral 
expression course taken by sophomore students in the major. Since students are less familiarized with international and national culture materials in English (as seen in this study), the researchers selected two different books for the proposal.

Table 5. Proposal to Maximize Language Competence and Culture in Oral Expression and Composition Courses

\begin{tabular}{|c|c|c|c|}
\hline $\begin{array}{l}\text { Folktale/Short } \\
\text { Story Chosen }\end{array}$ & Theme & Oral expression & Composition \\
\hline $\begin{array}{l}\text { International } \\
\text { Culture } \\
\text { Folktale: } \\
\text { "The Tiger's } \\
\text { Whiskers" }\end{array}$ & $\begin{array}{l}\text { Love, } \\
\text { marriage, } \\
\text { separation }\end{array}$ & $\begin{array}{l}\text { Listening Skill } \\
\text { - } \quad \text { Listening to the Story } \\
\text { - } \quad \text { Doing some exercises } \\
\text { - } \quad \text { Speaking Skill } \\
\text { - } \quad \text { Acting out a dialogue } \\
\quad \text { from the short story }\end{array}$ & $\begin{array}{l}\text { Writing } \\
\text { process to } \\
\text { write a letter } \\
\text { to get advice } \\
\text { from the } \\
\text { author of a } \\
\text { newspaper } \\
\text { column }\end{array}$ \\
\hline $\begin{array}{l}\text { National } \\
\text { Culture } \\
\text { Short Story: } \\
\text { "The Braid" }\end{array}$ & $\begin{array}{l}\text { Teen } \\
\text { pregnancy }\end{array}$ & $\begin{array}{l}\text { Listening Skill } \\
\text { - } \quad \text { Listening to the Story } \\
\text { - } \quad \text { Doing some exercises } \\
\text { - } \quad \text { Speaking Skill } \\
\text { - } \quad \text { Impersonating } \\
\quad \text { a character and } \\
\quad \text { participating in a talk } \\
\text { show }\end{array}$ & $\begin{array}{l}\text { Writing } \\
\text { process to } \\
\text { compare } \\
\text { and contrast } \\
\text { issues in the } \\
\text { short story. }\end{array}$ \\
\hline
\end{tabular}

Source: Results of the study. 
The first book, World Folktales: An Anthology of Multicultural Folk Literature, ${ }^{18}$ is a collection of folktales from around the world. Each folktale explores a theme related to birth, childhood, marriage, divorce, love, challenges and adventure, death, inheritance, bad habits, true friendship, superstitions, depression, beauty, luck, adoption or jealousy (see table 6). This book entails 18 folktales representative of 18 different international cultures. It also includes exercises before and after each tale to reinforce the four linguistic skills. For this proposal, the folktale The Tiger's Whisker was chosen for this first stage of the proposal. Some of the sequences of exercises were adapted from the original source to respond to the main findings of this study.

Table 6. Folktales and Cultures Represented in the Folktales of the Book World Folktales: An Anthology of Multicultural Folk Literature

\begin{tabular}{|l|l|l|}
\hline Folktale & $\begin{array}{l}\text { Culture } \\
\text { represented }\end{array}$ & Theme \\
\hline Why the Baby Says "Goo" & Native American & Birth and childhood \\
\hline $\begin{array}{l}\text { The Little Daughter of the } \\
\text { Snow }\end{array}$ & Russian & $\begin{array}{l}\text { Birth and childhood } \\
\text { Adoption }\end{array}$ \\
\hline The Boy of the Red Sky & Canadian & Birth and childhood \\
\hline The Spoiled Child & Slavic & $\begin{array}{l}\text { Birth and childhood } \\
\text { Children upbringing }\end{array}$ \\
\hline $\begin{array}{l}\text { The Fisherman and the } \\
\text { Genie }\end{array}$ & Arab & $\begin{array}{l}\text { Challenge and adventure } \\
\text { Luck }\end{array}$ \\
\hline
\end{tabular}

18 Anita Stern. World Folktales: An Anthology of Multicultural Folk Literature (Lincolnwood, IL: National Textbook Co., 1994). 


\begin{tabular}{|c|c|c|}
\hline $\begin{array}{l}\text { The Woodsman's Daughter } \\
\text { and the Lion }\end{array}$ & Puerto Rican & $\begin{array}{l}\text { Challenge and adventure } \\
\text { Keeping promises }\end{array}$ \\
\hline The Lucky Charm & Guatemalan & $\begin{array}{l}\text { Challenge and adventure } \\
\text { Jealousy }\end{array}$ \\
\hline Nazar the Brave & Armenian & $\begin{array}{l}\text { Challenge and adventure } \\
\text { Bravery }\end{array}$ \\
\hline The Shah Weaves a Rug & Iranian & $\begin{array}{l}\text { Challenge and adventure } \\
\text { Leadership, crime }\end{array}$ \\
\hline The Tiger's Whisker & Korean & $\begin{array}{l}\text { Love and Marriage } \\
\text { Arranged marriages }\end{array}$ \\
\hline The Giant's Bride & Scandinavian & $\begin{array}{l}\text { Love and Marriage } \\
\text { Beauty, Dating }\end{array}$ \\
\hline The Love Crystal & Vietnamese & $\begin{array}{l}\text { Love and Marriage } \\
\text { Bad habits }\end{array}$ \\
\hline $\begin{array}{l}\text { How Juan Married a } \\
\text { Princess }\end{array}$ & Filipino & Love and Marriage \\
\hline The Blue Rose & Chinese & $\begin{array}{l}\text { Death and Inheritance } \\
\text { Family jealousy } \\
\text { Preparing a will }\end{array}$ \\
\hline A True Hero & Mexican & $\begin{array}{l}\text { Love and Marriage } \\
\text { Arranged marriages }\end{array}$ \\
\hline A Chief Names His Heirs & West African & Death and Inheritance \\
\hline The Skeleton's Dance & Japanese & $\begin{array}{l}\text { Death and Inheritance } \\
\text { Bad habits, Superstitions } \\
\text { True friendship }\end{array}$ \\
\hline The Voyage Below the Water & Haitian & $\begin{array}{l}\text { Death and Inheritance } \\
\text { Depression, Sadness } \\
\text { Mourning period }\end{array}$ \\
\hline
\end{tabular}

Source: World Folktales: An Anthology of Multicultural Folk Literature, Anita Stern. 
The second book is the English translation of Cuentos de angustias y paisajes, by Carlos Salazar Herrera, a very well-known icon of Costa Rican literature. Costa Rican Short Stories of Anguish and Landscapes ${ }^{19}$ includes 30 short stories about significant themes such as love, disloyalty, unrequited love, revenge, and the struggles against nature (table 7). This book was first translated into English in 2016 by the María Luz Méndez. Based on the findings of this study, the researchers opted for including this resource in the proposal. The activities follow the same pattern as in the section of the booklet for international culture material. Therefore, the proposal encompasses the use of listening, speaking, and writing as well as reading activities before, during and after reading the short story or the folktale. It also involves role plays (such as a talk show), acting out parts of the story, writing a letter from one character to a newspaper columnist, and comparing or contrasting patterns or issues found in the text.

19 Carlos Salazar Herrera and María Luz Méndez Salazar (trans.), Costa Rican Short Stories of Anguish and Landscapes (Heredia, C. R.: EUNA, 2016); translation of: Carlos Salazar Herrera, Cuentos de angustias y paisajes (San José: El cuervo, 1947). 
Table 7. List of Short Stories of the Book Short Stories of Anguish and Landscapes and Their Main Themes

\begin{tabular}{|c|c|}
\hline Short Story & Theme \\
\hline The Bocaracá & Fear, danger, desperation, frustration \\
\hline The Bridge & Courtship, dating, work, unrequited love \\
\hline $\begin{array}{l}\text { The Limestone } \\
\text { Quarry }\end{array}$ & Jealousy, cheating, \\
\hline The Young Bull & Hatred, revenge \\
\hline The Gourd & Separation, disease, hope, suffering \\
\hline The Bongo & A lost love, teen escaping from home \\
\hline Ambushed & Crime, revenge \\
\hline The Witch & Witchcraft, love, gossip, lost love \\
\hline The Cricket & Loneliness, depression, sadness \\
\hline The Kiss & Suicide, desperation, jealousy \\
\hline The Shout & Grief, distress, frustration, desperation \\
\hline The Window & Gratitude, faithfulness, patience \\
\hline The Dulzaina & Illusion \\
\hline The Mestizo & Unfaithfulness, marriage \\
\hline The Colors & Alcoholism, loyalty \\
\hline The Boatman & Revenge \\
\hline The Drought & Family communication, separation, divorce. \\
\hline The Rainstorm & Insanity, death \\
\hline The Marsh & Disappointment, frustration, love, friendship \\
\hline The Folk Healer & Unfaithfulness \\
\hline
\end{tabular}




\begin{tabular}{ll}
\hline The Braid & Teen pregnancy \\
\hline The Halfbreed & Family violence \\
\hline The Still & Repentance for being disloyal to oneself \\
\hline The Mountain & Jealousy, crime \\
\hline The Hours & Passion, humiliation \\
\hline The Road & Sacrifice, suffering \\
\hline The Chilamate Tree & Death, love \\
\hline One Night & Fear, anxiety \\
\hline A Gasp of Air & Jealousy, crime \\
\hline The Dugout & Life, bravery, cooperation \\
\hline
\end{tabular}

Source: Short Stories of Anguish and Landscapes

The proposal and the design of the booklet resulting from this study are an attempt to bridge the gap between the teaching of the language and the teaching of cultural awareness. Whether taught in isolation or separately in different courses, it is not an easy endeavor. Ultimately, it is possible to blend world and home cultures with language competence to maximize the students' development of written and oral skills. It requires a willingness to foster the use of valuable cultural material such as short stories and folktales in the corresponding courses. 